Journal of Economics and Behavioral Studies

Vol. 4, No. 11, pp. 625-634, Nov 2012 (ISSN: 2220-6140)

\title{
Motivators of Construction Workers in the South African Construction Sites: A Case Study
}

\author{
Thwala, W. D*, Monese, L. \\ University of Johannesburg, South Africa \\ *didibhukut@uj.ac.za
}

\begin{abstract}
Construction industry involves laborious and hazard work because of its demands it requires energetic and enthusiastic people and this are the attributes that in most cases young people poses. Construction industry stakeholder should shift their attention and prioritize the motivation of its workers since the industry has a way of cubing poverty and uplifting the county's economy. This study used data from both primary and secondary sources a special focus on leadership and human resource management context. A survey was conducted with managers and employees regarding motivation on construction site were conducted at different parts of Gauteng. Furthermore, employees work because they obtain something that they need from work and that something obtained from work impacts morale, employee motivation, and the quality of life. Workforce motivation affects productivity. Because most of the activities are done under difficult conditions including harsh weather conditions, to make it attractive employees should be motivated to carry out different activities. Motivators should be in place to improve the chances of the industry's competitiveness both locally and internationally.
\end{abstract}

Key words: Productivity, motivation, job satisfaction, morale, human resource, construction

\section{Introduction}

The success of any business can be attributed to the motivation of the employees. From the point of recruitment to retention, a company's profitability and productivity can be attributed to hardworking and happy employees. This is especially true and important in today's turbulent and often chaotic environment whereby the commercial success depends on employees using their full talents. The ability to attract, retain and develop talented employees is a key feature of a successful business. People are organization's most valuable asset and this is especially true in relatively low-tech labor intensive industries such as construction, but again, workers are the most difficult resource for organizations to manage. Unlike physical assets, workers have their own individual needs and habits, which must be met be managed if they are to contribute to organizational growth and development. Workers bring their own perspectives, values and attributes to organizational life, and when managed effectively can bring considerable benefits to organizations (Mullins 1999). However, when managed poorly they have the potential to severely limit organizational growth and threaten the viability of a business. In any organization, whether it is a construction company or any other trade, its core is its employees; their presence and contribution is very important in such a way that they determine if the company is going to be a success or failure. A company may have good manager, with a good vision and a goal; however, if the employees are neglected, that company is practically going to be in turmoil. Unsatisfied employees produce unsatisfied results, therefore, it is essential for top management to take care of their employees to ensure that they are satisfied in their jobs. When they are satisfied, they strive to achieve the company's goals and aims (Latham 1994). Construction is an industry with unique characteristics, which may have special effects on employee motivation, and it should be noted that even though a construction projects takes months to complete, daily satisfaction surely accompanies the work as it is done. In any work environment of any field, motivation of the workforce influences productivity, job satisfaction plays an important role in enhancing construction workers productivity (Smithers and Walker, 2000), and this forms the basis for identification of the work environment factors.

Purpose of the Paper: The main objective of this paper is to establish the motivators of the construction workers in South Africa. This is due to the fact that it is only when worker are adequately motivated that they can become productive, take pride in their jobs and be loyal to their employers. The paper also identifies what de-motivates workers and how workers can be retained thereby limiting job-hopping. 


\section{Literature Review}

Like in most parts of the world, construction industry plays a very important role both directly and indirectly as a contributor to South African economic growth; it is a significant employer of people because of its ability to "absorb the excluded" creating numerous economic opportunities for medium and small enterprises (Thwala, 2008). Its products have an amazingly long life and they unleash abundant economic opportunities for their consumers; and contribute directly to improving the quality of life of its users. The sector employs the fourth-highest number of persons who have no education, the first being agriculture, followed by households and mining. The industry is dominated by a few major players, who account for $75 \%$ of the industry's total output sharing almost all the major civil engineering projects among themselves with overseas joint venture partners. Although the industry is current contribution to the gross domestic product has shrunk to approximately $3 \%$, compared to $7 \%$ in the 1970 's, it remains an important economic sector (International Conference on Construction in the 21st Century, 2002). It is estimated that building construction makes up roughly two thirds of the contribution of the GDP and civil engineering making up most of the balance (CIDB, 1997). According to Statistic South Africa (2005) 461000 people were employed in 2006, which represents a rise of $21 \%$ in that period compared with 381000 jobs available in 2004. This means that about 80000 additional jobs were created in construction during those past two years. Total gross earnings rose from R6bn in 2004 to R8bn in 2006. Statistics South Africa employment figures suggests that in 2006 the construction sector was responsible for $8 \%$ of the total national employment causing an increase from the 2001 contribution of $6 \%$. It is also estimated that the construction sector employs one million people, with some 424000 individuals employed in the formal sector. The total income for the construction industry in 2004 was R100 442 million. The main contributors to the total income were 'construction of buildings' with R33 117 million (33,0\%), 'construction of civil engineering structures' with R27 478 million $(27,4 \%)$, 'other building completions' with R10 625 million (10,6\%) and 'other building installations' with R8 992 million $(8,9 \%)$.

The nature of the construction industry exposes workers to factors that could lead to demotivation. These factors range from harsh weather conditions, transient workforce, lack of skills development and training to its recruitment practices. All of these factors require management to make motivation and job satisfaction of the workers a priority, in order for the industry to be productive. Motivation is the set of processes that moves a person toward a goal, thus, motivated behavior is a voluntary choice controlled by an individual. Factors that affect work motivation include individual differences, job characteristics and organizational practices. Individual differences including personal needs, values, and attitudes, interests and abilities are what people bring to their jobs. Job characteristics are the aspects of the position that determine its limitations and challenges. Organizational practices are the rules, human resources policies, managerial practices, and rewards systems of an organization. Supervisors must consider how these factors interact with one another to affect the employees' job performance since employee motivation is an important part of managing employees given that motivation is directly linked to job performance. For any business, be it big or small, production is of great importance because the particular business succeeds in gaining position in the market and through this earn higher sales, which converts into "profit". Therefore, it is essential for employers to be aware of the aspects of maintaining a stable and reliable productivity to satisfy their clients. It is only through best practice that business with continuous performance can bring about quality production, and to do so, the venture must have a knowledgeable management and process improvement plans in place.

Motivation: Motivating (motivation) is the ability of programming personnel with a unity of purpose and maintaining a continuing, harmonious relationship among all people (state the referenced source). Likert (1961) described motivation as an organize efforts of individuals to achieve a desired objective. The definition was reflected upon by Ribeaux and Poppleton (1978), which asserted that workers only do things because they are motivated to do so either by choice or by coercion. Motivation is a force, which encourages and promotes a willingness of employees to cooperate with other members of the team. Luthans (1998) further asserted that motivation is the process that arouses, energizes, directs, and sustains behavior and performance, that is, it is the process of stimulating people to action in other to achieve a desired task. He again stress that, like the other cognitive process, motivation cannot be seen, all that can be seen is behavior, and this should not be equated with the causes of behavior. Motivation is the ability of indoctrinating the personnel with a unity of purpose and maintaining a continuing, harmonious 
relationship among all people. A common phase in all definition are words such as "desire", "want", "wishes", "aim", "goals", "needs", and "incentives" (can you please state how this words explain the concept of motivation). In conclusion motivating is the work managers perform to inspire, encourage and impel people to take action. To motivate the employees, an employee must be reached and to reach him there must be a complete understanding of the complexity of his make-up (Allen, 2001). Worker enhancement programs (for individual, team, company, amongst others) that are built on ways to motivate workers (toward self-motivation and long-term motivation) can optimize productivity. Thus, lack of motivation in return affects productivity and a number of symptoms such as poor workplace atmosphere, high employee turnover, increasing number of grievances, conflicts, higher incidence of absenteeism and tardiness, increasing number of defective products, rework, higher number of accidents or a higher level of waste materials and scrap (Monese and Thwala, 2009). When workers are demotivated, they become disengaged yet they still remain in the workforce and are unable to improve and unable to respond to new demands. Motivation of the labor force is of paramount importance because the quality of human performance at the workplace, which brings about increase productivity, depends largely upon motivation. Productivity is directly linked to motivation, and motivation is, in turn, dependent on productivity.

Motivation Theory: Literature on management and organization has presented several models to explain worker motivation and in some case the lack of such motivation. These extend back to scientific management by Taylor (1947), to the human centered management theory of McGregor (1960) to the current issues of power and discourse of Jackson and Carter (2000). However, the following motivation concepts have commonly been applied to increase productivity in construction projects:

- Theory of Maslow (1954) based on hierarchy of human needs

- Two-factor Theory of Herzberg et al. (1959) based on hygiene factors and job enrichment factors

- Theory X and Theory Y of McGregor (1960) based on ways of perceiving workers

- Expectancy theories of Vroom (1964) and Lawler (1973)

- Theory Z of Ouchi (1980) based on holistic concern for employees

- Motivation schemes under the current practice of Total Quality Management in projects (TQM).

Can you please explain why you think this is necessary- because I am very sure that most researchers in the field of management (motivation theory) should be well aware of these theories? Don't you think so? Alternatively, you should restructure the content to give it a voice. Maslow (1954) introduced the notion of a hierarchy of needs and said that different needs stimulate different levels and once a level has been satisfied, it ceases to be effective, and a higher level need is sought after. Likewise, a higher level need will not be an effective stimulant if the lower level has not been satisfied. The order proposed by Maslow is (1) physiological, followed by (2) safety, (3) affiliation, (4) self esteem and esteem from others, and ultimately (5) self-actualization. This hierarchy of needs theory is based on the principle that people are motivated by the desire to fulfill their needs and set goals to satisfy their needs; in the absence of any other needs there would be no motivation. Herzberg (1959) offered the concept of dual factor motivation theory, which he termed motivation factors and hygiene factors. According to him, hygiene factors such as company policy, supervision, salary, interpersonal relations, working conditions, status and security can cause dissatisfaction either due to a lack of them or their being perceived as inappropriate. Motivating factors such as recognition, work itself, responsibility, advancement and growth alone will not bring about motivation if the factors are not satisfied. Likewise, the satisfaction of all hygiene factors without the presence of motivators will not bring about motivation. The content factors tend to motivate by their presence while the context or hygiene factors dissatisfy individuals when they are deficient, that is, dissatisfies are deficit needs. For example, poor working conditions are commonly named as the source of dissatisfaction, but good physical working conditions are rarely named as being the source of worker satisfaction. Herzberg developed the theory on the basis's that workers' mental health is associated with performing meaningful work. McGregor (1960) came up with two motivational models calling them " $\mathrm{X}$ " and " $\mathrm{Y}$ ". Theory $\mathrm{X}$ model the authoritarian management style is based on the idea that people naturally don't like to work, lack ambition, and therefore need to be compelled to work. It is the traditional view of direction and control whereby the function of management is to force the employee to work, through coercion and threats of punishment. The main motivator for the worker under this theory is therefore money. Theory $\mathrm{Y}$ the participative management style is the predominant management style used in the 
construction industry. It states that management holds the power and exerts control over the workforce. It states that work is natural and can be a source of satisfaction and that when it is; the worker can be highly committed and motivated. Workers often seek responsibility and need to be more fully involved with management to become motivated. In addition, that people prefer to set his or her own goals and seek responsibility rather than avoid it.

Vroom (1964) research was on expectancy theory, which is based on the belief that employee effort will lead to performance, and performance will lead to rewards. This theory argues that the motivational force to perform or expend effort is a multiplicative function of the expectancies that individuals have concerning future outcomes and the value they place on those outcomes (Vroom 1964; Maloney 1997; Laufer, Jenkins 1982). Rewards may be either positive or negative. The more positive the reward the more likely the employee will be highly motivated. Conversely, the more negative the reward the less likely the employee will be motivated. Ouchi (1980) in his model (Theory Z) he advocates a combination of the best of theory Y and modern Japanese management, placing a large amount of freedom and trust with workers, and assumes that workers have a strong loyalty and interest in team working and the organization. Many Japanese employees are guaranteed a position for life, which increases their loyalty to the company. He described the characteristics of the Japanese companies that produce high employee commitment, motivation, and productivity; careful evaluation occurs over a period, and the responsibility for success or failure is shared among employees and management. Most employees do not specialize in one skill area, but work at several different tasks, learning more about the company as they develop. According to Ouchi, (1980) Theory Z management tends to promote stable employment, high productivity, high employee morale and satisfaction.

\section{Methodology}

Sample and Data Collection Procedure: The Gauteng province is made up of three metropolitan municipalities that is, City of Johannesburg, City of Tshwane and City of Ekurhuleni. Gauteng is the smallest province in South Africa, with only $1.4 \%$ of the land area, but it is the most highly urbanized and wealthiest province. Although Gauteng is the smallest province in South Africa, it contributes 33.9\% of its gross domestic product (GDP). It further generates $10 \%$ of the GDP of the entire African continent. The research was conducted in Gauteng to managers and the employees of selected construction companies. The size of the companies ranged from small, medium to big companies and the study embraced both the main contractors and sub-contractors. A preliminary set of semi-structured interview was carried with managers and employees at various levels of an organization in order to establish the motivators and its effect on construction productivity. A primary survey of construction employees working around the Gauteng Province was conducted in South Africa in 2009. According to Love, Sing, Wang, Irani, and Thwala (2012) where availability and access to databases and case studies is limited a questionnaire survey can be adopted. The questionnaire method enables the researcher to collect data from large number of potential respondents within a short period and makes a possible quantitative analysis to be much to be done. The survey sample included managers and construction sites workers around the Gauteng Province. The Gauteng Province has the highest concentration of construction companies and construction workers. South Africa have eleven official languages, however English is used for conducting business. The quantitative data was collected via structured questionnaires. The survey was carried out on 45 construction companies. The targeted contractor population was 100 contractors who held valid registration from the Construction Industry Development Board (CIDB). The questionnaire was administered to 90 managers in all different capacities such as directors, partners, project managers and construction managers. Also were 150 workers occupying different trades and occupations such as bricklayers, plumbers, electricians, and carpenter and amongst others were interviewed. 
Figure 1: Research Process

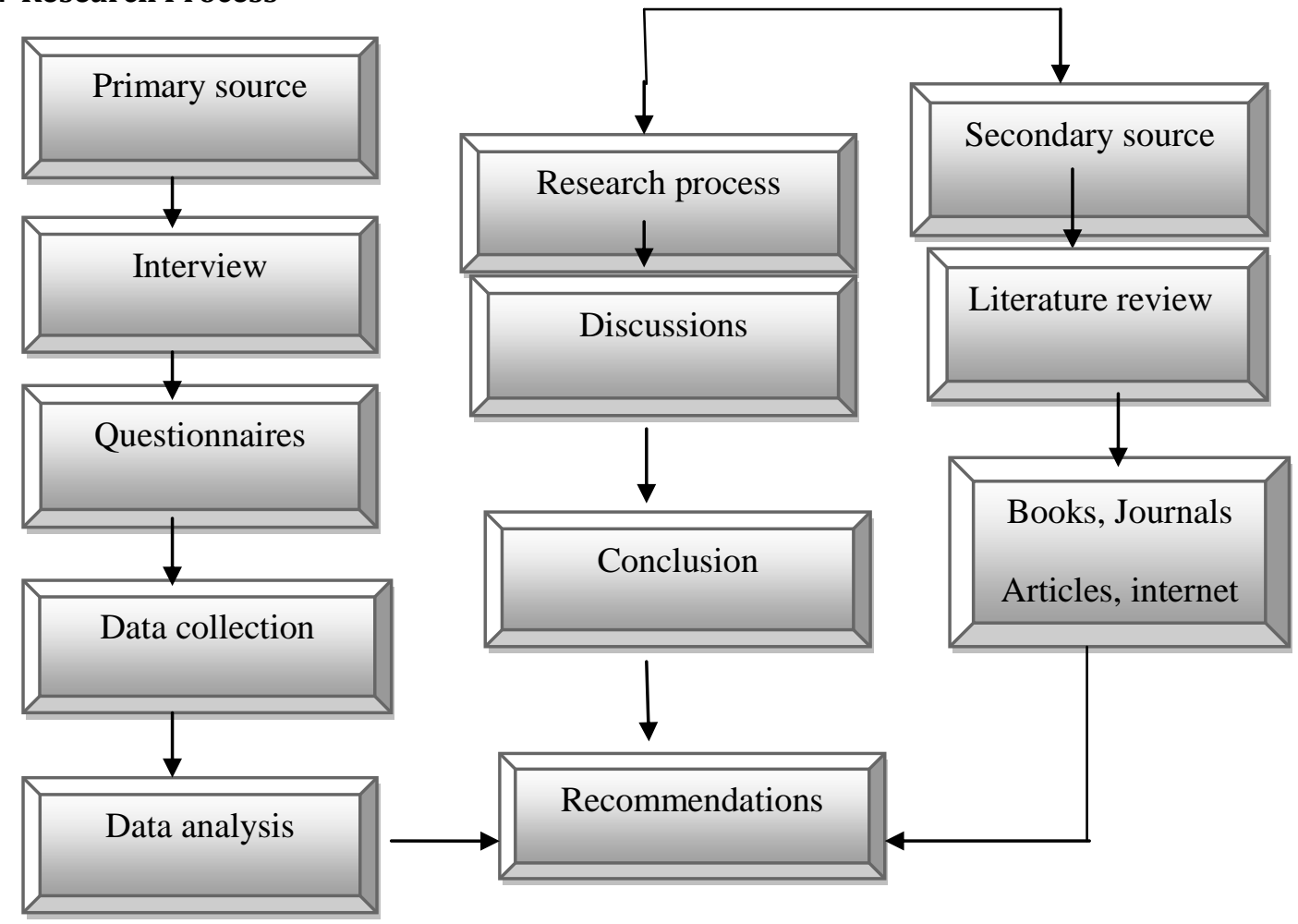

Instrument: A questionnaire was used for data collection. A total of 230 questionnaires were distributed to 45 construction companies. This included 90 questionnaires distributed to managers and 140 questionnaires to construction sites workers. Random sampling method was used to undertake the survey. The data was collected over 8 weeks. Of the 230 questionnaires that were distributed, 184 sets were returned. The rate of return was 80 percent the sample size was large enough to be representative of the views of the managers and employees working on the construction site. A cover letter was enclosed in each of the questionnaire to explain the objective of the study and the preservation of their confidentiality. It was clearly stated in the letter that participation is voluntary.

\section{Data Analysis and Findings}

Gauteng is one of the nine provinces that make up the country of South Africa, which is located in the Southern part of Africa. Gauteng Province is currently home to 10.45 million people (Community Survey, 2007), as against 9.18 as reported in the 2001 South African National Census which was, almost $20 \%$ of the total South African population. Gauteng Province is also the fastest growing province, experiencing a population growth of over 20\% between the 1996 and 2001 censuses, and currently 13.9\% (Statistics South Africa, 2005).

\section{Map of the Study area}

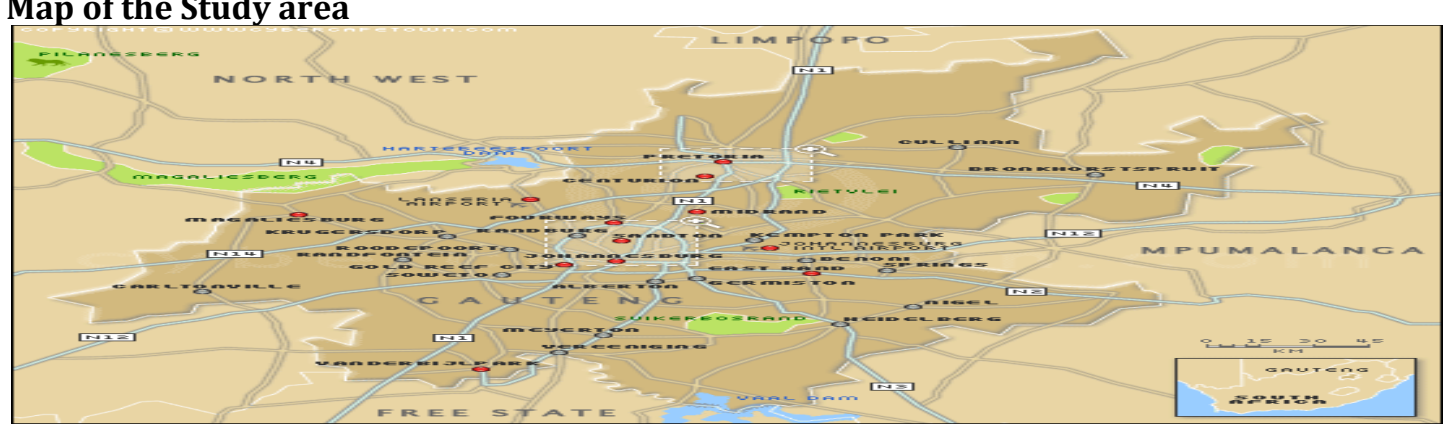

Map 1 Source : www.cybercapetown.com, 2012 
Figure 2: Demographic characteristics of respondents

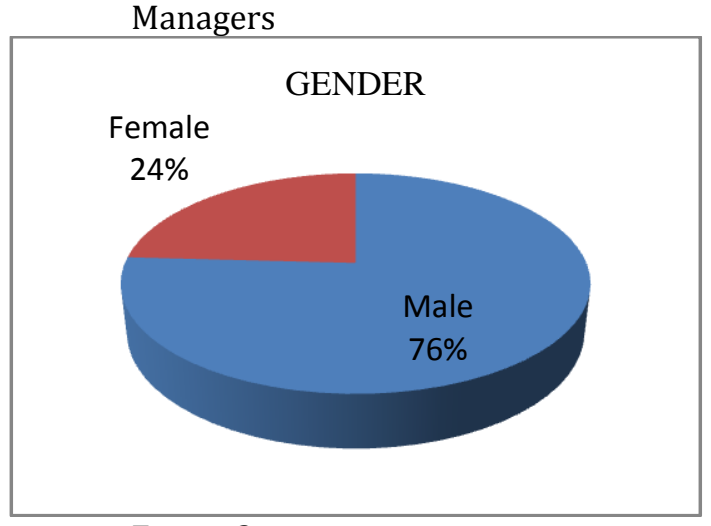

Figure 2a

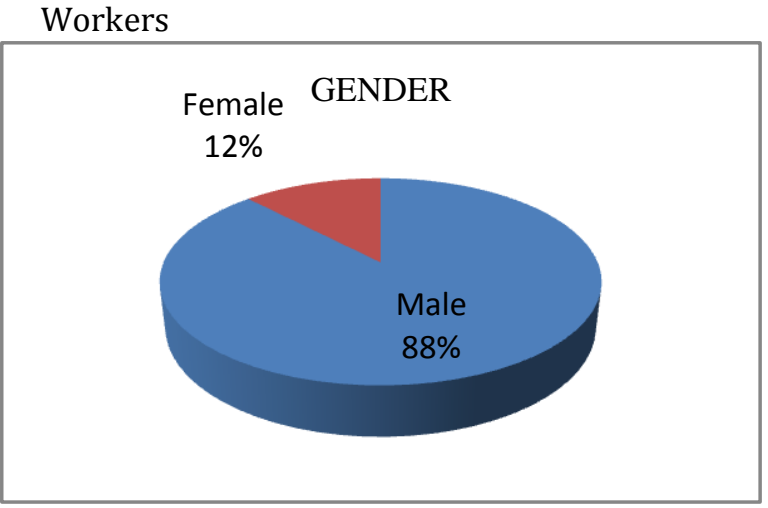

Figure $2 b$

The charts above indicate that out of $100 \%$ of managers (Figure $2 \mathrm{a}$ ) majority of respondents are males $(76 \%)$ and $24 \%$ being females. In the case of workers as in figure $2 \mathrm{~b}$ above, the same situation applies where $(88 \%)$ of the respondents, are male and $12 \%$ are female. In both cases, the dominance of males exists. This reinforces the study by Dainty et al (2000) and Maloney (1997) regarding the dominance of men in the industry. Again, the increase in percentage of females especially on managerial positions could be because of the Black Economic Empowerment (BEE) requirements for tender adjudication purpose. The ages of managers varied from 33 to 77, however, majority (43\%) is between 41 and 50 years, 33-40 and 61-70 made up 18\%, and 51-60 made 17\%, with the least percentage being $4 \%$ for 71 77 years. On the results of the workers, the ages of the participants that dominated was 31-40 with 71\%, 23-30 making 20\% and 41-50 making 9\%. Regarding ethnicity, 61.4\% in managerial positions was black, $23.9 \%$ was white and14.8 percentage was colored. Again, black workers dominated, making 85\%, 6.1\% white and $6.8 \%$ was colored.

Figure 3: Managers To what extent do you agree with each of the following statements? - Your workforce is best motivated when...

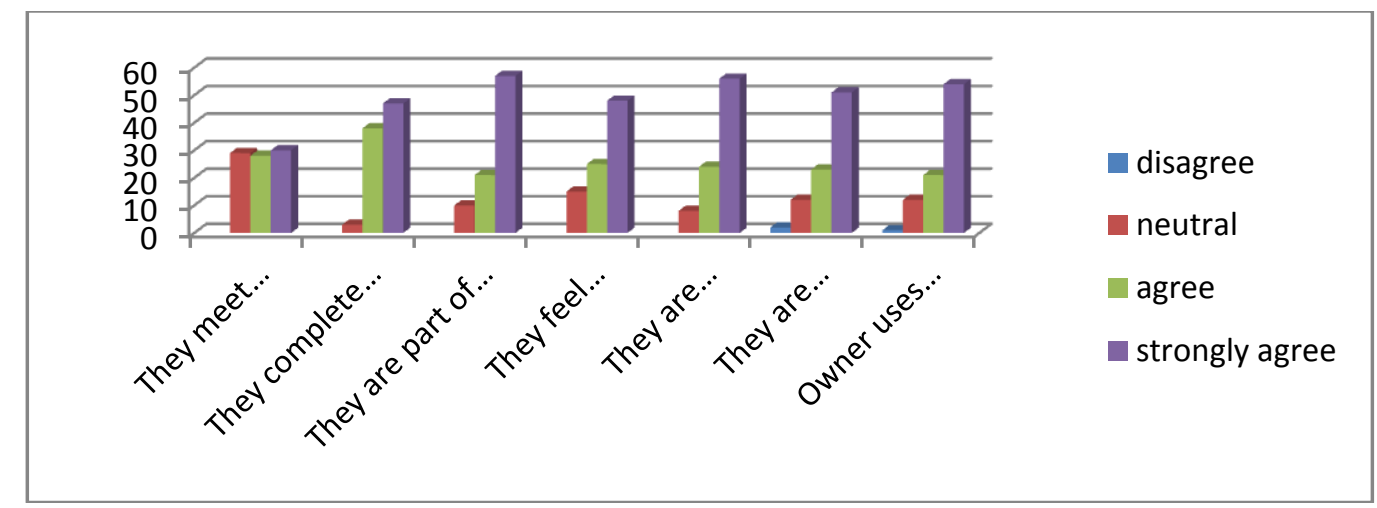

The data suggests that all motivator are important; as a result, all of them had the biggest numbers, but "being part of the team" (57) and workers' "empowerment" (56) were seen as the most important motivators by the employers. On the other hand "meeting project schedule" (30) was the least motivator by the employers when it comes to their workers. "Being part of the team" had a percentage value of 64.8\% and "empowerment" had 63.6\%. 
Figure 4: In order to motivate your workforce, how important are the following needs? Please indicate your answer using the following 3-point scale

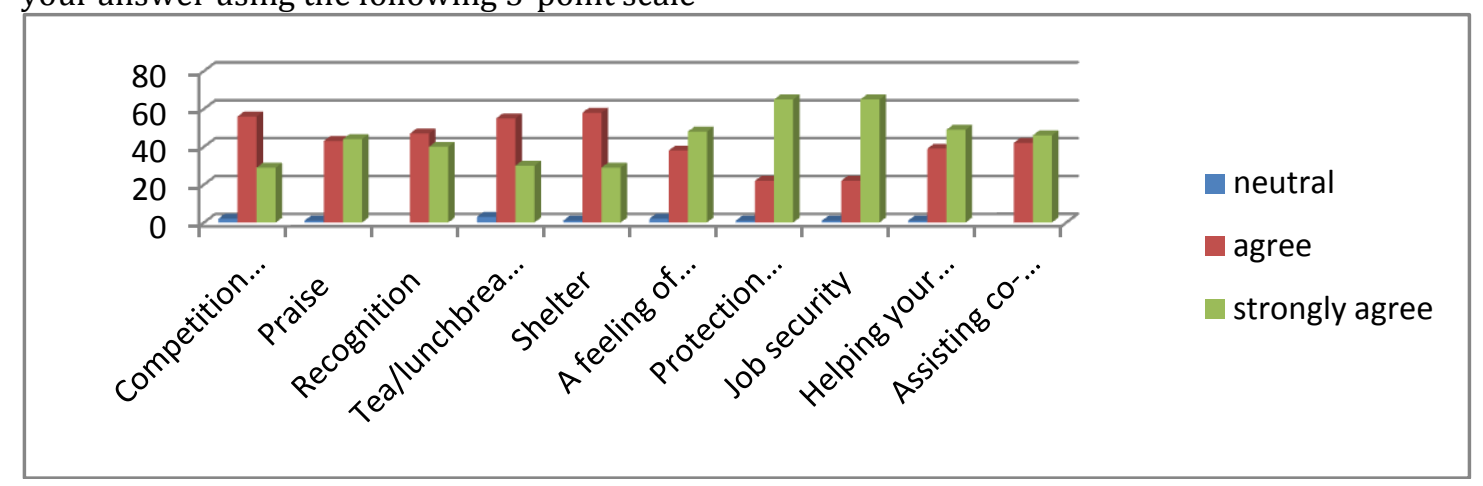

Regarding the best manner of motivating the workforce, the employers strongly agreed that job security and protection against danger (65) were the most important needs, whilst competition between team members, shelter (29) tea/lunch breaks were least important to the workers.

\section{Figure 5: Employee-based productivity improvement techniques}

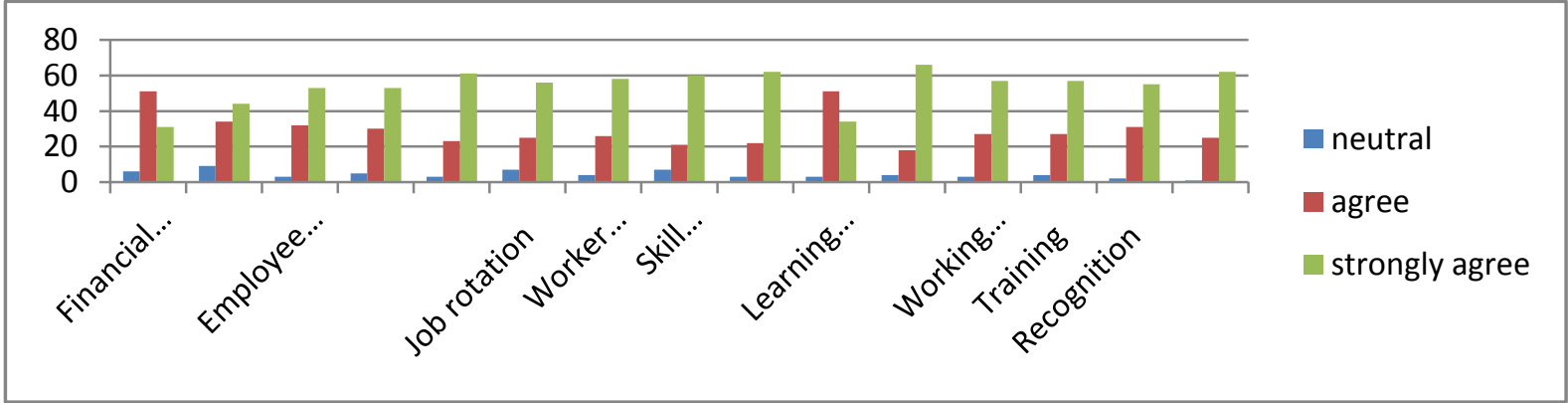

Almost all employers strongly agreed that communication (66), quality control circles (62), management by objective (62), job enlargement (61) and skills enhancement (60) are most important employee-based productivity improvement techniques. In addition, surprisingly financial incentives (31), learning curve (34) and fringe benefits (44) were not seen as productivity improvement techniques

Figure 6: To what extent do you agree with each of the following statements? Please indicate your answer using the following 3-point scale where:

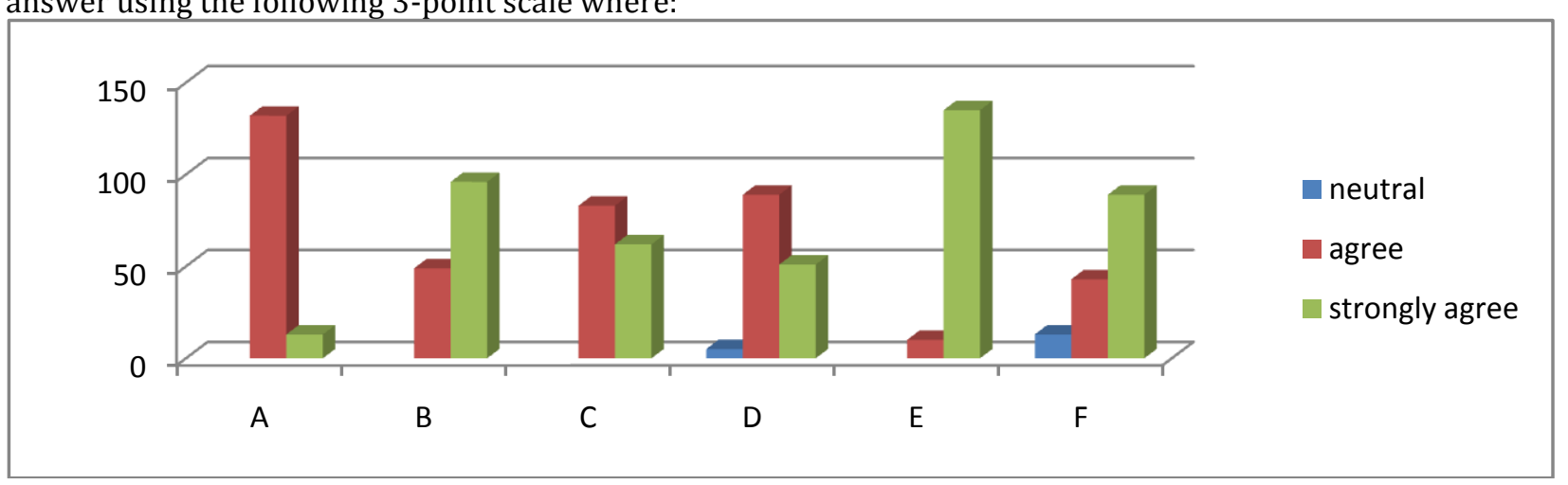

Majority of the workers strongly agreed that being empowered (135), completing the project (96), and being self-motivated (89) are the most important motivators; on the other hand meeting project schedule (13) was not a big motivator the workers. 
Figure 7: How important is each of the following worker needs in terms of motivation?

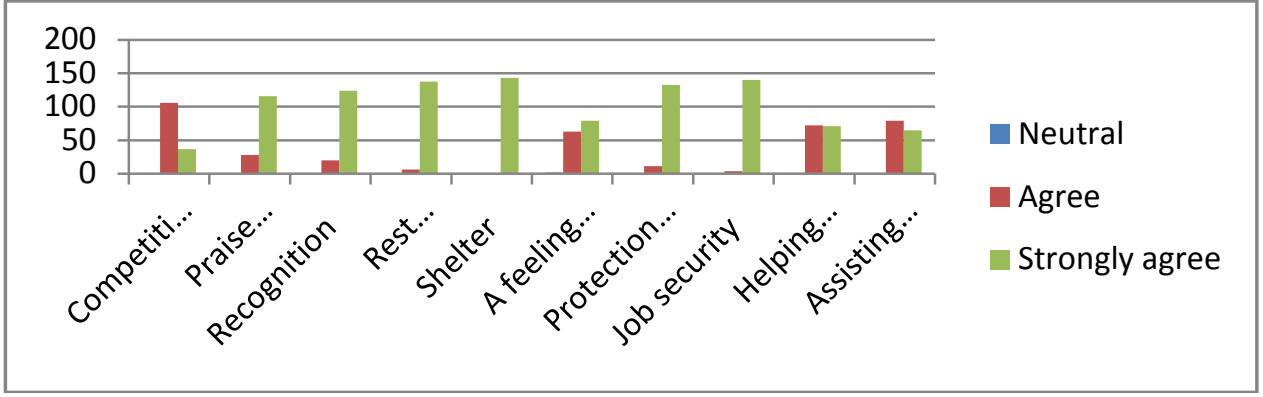

Shelter (143), job security (140), rest (Tea/lunch breaks) (138), protection against danger (133), recognition (124), praise (116) were more favored by the workers. In addition, the remaining motivators: competition with other team members (37) had the least value of 37.

Figure 8: Please mark in order of importance each of the following incentives

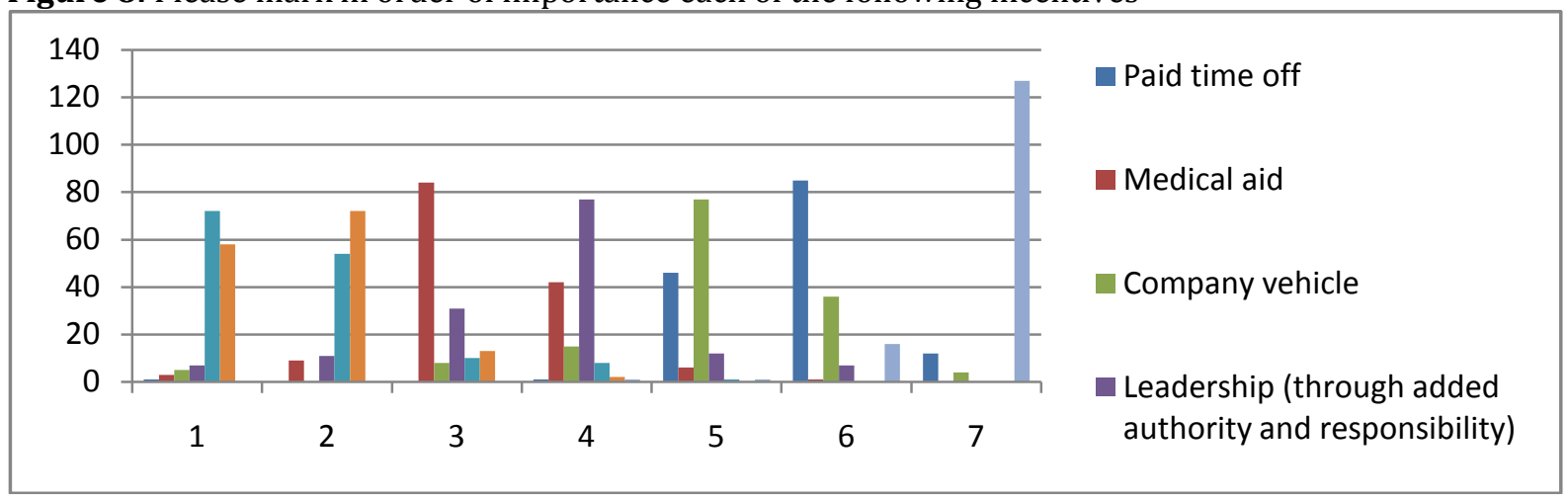

When asked to rank the motivators in the order of importance, the surveyed workers ranked "merit bonuses" $1^{\text {st }}$ with a total of 72, "year increase above inflation" ranked $2^{\text {nd }}$ with a total of 72 , "medical aid" was ranked $3^{\text {rd }}$, "leadership" ranked $4^{\text {th }}$, "company vehicle" was in the $5^{\text {th }}$ position, "paid time off" ranked $6^{\text {th }}$ and majority of the workers were not concerned about "month-end parties". The findings of this study reveal that a relationship exists between motivation, job satisfaction, and commitment and productivity. No difference was observed in the perceived motivation of the managers and the workers. Moreover, findings also showed that differences existed in the job satisfaction of the workers as seen by the managers and the way workers see it. The link that exists in this study among others include perceived work motivation, job satisfaction, and commitment corresponds with the study of Brown and Sherpard, (1997) who reported that motivation improves workers' performance and job satisfaction. The result also agrees with Vinokur et al., (1994) who reported that certain motivational factors contribute to the prediction of job satisfaction. The study revealed that none of the participants denied that motivational is essential in improving productivity According to the results; respondents agree that motivators and job satisfiers are essential to keep the workers happy and productive. Employee motivation is an important part of managing employees. This is because motivation can be directly linked to job performance. There are several different motivation techniques that can be applied, many of which are universal and others, which are dependent upon the situation, employee, department, or overall company. The findings further reveal that according to the managers the workforce is best motivated by safety needs (job security and protection from danger) which appear on the second level of Maslow's Hierarchy of needs, which are the same as hygiene factors on Herzberg's dual theory. Surprisingly, Physiological needs were not very influential according to the managers, for instance, tea break and shelter were listed last on the ranking by the mangers. On the techniques that could be used for productivity improvements communication was ranked as very important, which was followed by quality control circles, management by objectives , job enlargement, skill enhancement, worker participation, training, working conditions improvement and job rotation. Surprisingly again, fringe benefits and financial incentives were least favored by the managers as motivators. This reinforces the idea that job content factors are more powerful than job context factors. 
Construction Project Success: Despite development in the project management technology, workers are still key players in the projects. They determine the success or the failure of a project as well as define project goals, they plan, organize, direct, coordinate and monitor project activities. This concludes that human resource management is a vital component of any project. The emphasis is on the workforce and how they can be managed and led to increase their overall efficiency and effectiveness as individuals, as project teams and as the members of the organization. It is important therefore, that the right people enter the project at the right time, are organized and motivated as individuals and work as a team to deliver according to the project goals and therefore recognized and rewarded for their achievements.

\section{Conclusion and Recommendations}

The ability to attract, retain and develop talented employees is a key feature of a successful business. People are an organization's most valuable asset and this is especially true in relatively low-tech labor intensive industries such as construction, but again, people also represent the most difficult resource for organizations to manage. Unlike physical assets, people have their own individual needs, which must be met, and habits, which must be managed if they are to contribute to the organizations' growth and development. They are individuals who bring their own perspectives, values and attributes to organizational life, and when managed effectively can bring considerable benefits to the organization (Mullins, 1999). However, when managed poorly they have the potential to severely limit organizational growth and threaten the viability of a business. In any company, whether it is a construction company or any other trade, its core is the employee. The presence and contribution of the employees is very important in such a way that they determine if the company is going to be a success or a failure. A company may have good manager, a good vision and a good goal but, if it neglects its employees, the company is practically in turmoil. Unsatisfied employees produce unsatisfied results. Therefore, it is very vital for top management to take care of their employees to ensure that they are satisfied with their jobs. When employees are satisfied, they strive towards company goals and aims (Latham 1994 ;). Construction is an industry with unique characteristics, which may have special effects on employee motivation and it should be noted that even though a construction project may take months to complete, daily satisfaction definitely accompanies the work as it is done. The paper has demonstrated that motivation plays an important role in the South African construction industry. Based on the findings in this paper, it can be concluded that workers ranked empowered as the first and most important motivator. Once an employee is empowered, he grows and his responsibility is enlarged and can decide and solve problems on his own on how to perform his tasks to suit him and the conditions in which he is working. In addressing, the challenges faced by the South African construction it is recommended that the different stakeholders take responsibility and participate more fully in development of the construction as follows:

- Government: Because of the devastating effects, that apartheid has had on the human resource potential of black people and its contribution to the poor economic performance and delivery of social services, the Skills Development Act and the related Skills Development Levies Act should be put more into practice and enforced. If these acts are to be compulsory, there will be a fundamental improvement regarding the relationship between education, training and the workplace. Measures must be taken to force the companies to provide training and skill development to their employees and in increase of levies should be provided for this purpose.

- Construction companies: through their organizational structure they, should motivate their employees for best result, good quality, loyalty, trust and lasting relationship. When companies invest in their employees, the companies will grow and attract more clients and improve their profitability. It is therefore necessary to use the different motivational technique so as to achieve better performance.

- Managers/supervisors: communication and feedback are the best part of building trust between the employer and the employee and mostly fair wages address the needs of the employees. Maybe it would be appropriate to develop some sort of formal/informal education and training modules or workshops for management as to how they can get the best out their employees. 


\section{References}

Allen, L. (2001). The Allen manager seminar: Effective management series. Louis, A. Allen associates, Parkwood.

Brown, J. \& Sheppard, B. (1997). Teacher librarians in learning organizations. Paper Presented at the Annual Conference of the International Association of School Librarianship, Canada. August 2530.

Construction Industry Development Board (CIBD). (2007). Skills for Infrastructure Delivery in South Africa, Pretoria, South Africa.

Dainty, A., Bagilhole, B. \& Neale, R. (2000). A grounded theory of women's career under-achievement in large UK construction companies in Construction Management and Economics. Taylor \& Francis Ltd: London.

Herzberg, F., Maunser, B. \& Snyderman, B. (1959). The Motivation to Work. John Wiley and Sons: New York, NY.

Latham, M. (1994). Constructing the Team, Joint Review of Procurement and Contractual Arrangements in the United Kingdom Construction Industry: Final Report. London: HMSO.

Laufer, A. \& Jenkins-Jr, D. G. (1982). Motivating construction workers. Journal of the Construction Division, ASCE, 108(4), 531-545.

Lawler, E. (1973). Expectancy Theory and Job Behavior. Organizational Behavior and Human Performance, 9(3), 482-503.

Lewis, J. (2001). Policies to Promote Growth and Employment in South Africa, Informal Discussion Papers on Aspects of the Economic of South Africa. No. 16, World Bank, July.

Likert, R. (1961). New Patterns of Management. New York, NY: McGraw-Hill.

Love, P. E. D., Sing, C. P., Wang, X., Irani, Z. \& Thwala, D. W. (2012). Overruns in transportation infrastructure projects. Structure and Infrastructure Engineering Journal, 18(4).

Luthans, F. (1998). Organizational Behavior. 8th ed. Boston: Irwin McGraw-Hill.

Jackson, N. \& Carter, P. (2000). Rethinking organizational behavior. Prentice Hall, Pearson Education Ltd, Harlow, Essex.

Maloney, W. (1997). Chile. In The Political Economy of Latin America in the Postwar Period, edited by Laura Randall. Austin: University of Texas Press.

McGregor, D. (1960). The Human Side of Enterprise New York, NY: McGraw-Hill.

Maslow, A. (1954). Motivation and personality. Harper and Row: New York.

Monese, L. N. \& Thwala, W. D. (2009). Motivators of Construction Workers in South African Sites. Published in the Proceedings of the $6^{\text {th }}$ Construction Industry Development Board Postgraduate Student Conference, Johannesburg, South Africa.

Mullins, A. K. (1999). Management and Organisational behaviour. Prentice Hall: New York.

Ouchi, W. G. (1980). Markets, Bureaucracies and Glaus. Administrative Science Quarterly, 25, 129-141.

Ribeaux, P. \& Poppleton, S. (1978). Psychology and Work, Macmillan.

Smithers, G. L. \& Walker, D. H. T. (2000). The effect of the workplace on motivation and demotivation of construction professionals. Construction Management and Economics, 18(7), 833-41.

Statistics South Africa. (2005). Labor Force Survey for September 2005. Statistics South Africa: Pretoria, South Africa.

Taylor, F. W. (1947). Scientific Management. New York: Harper \& Row.

Thwala, W. D. (2008). Employment Creation through Public Works Programme in South Africa: Challenges and Potentials. Acta Commercii Journal, 8, 103 - 112.

Vinokur, K. D., Jayaaratne, S., Chess, W. A. (1994). Job satisfaction and retention of social workers in public agencies, non-profit agencies and private practice: The impact of work place conditions and motivators. Administration in Social Work, 18(3), 93-121.

Vroom, V. H. (1964). Work and motivation. Wiley: New York. 